\title{
A new havanensin-type limonoid from Chisocheton macrophyllus
}

\author{
Nurlelasari ${ }^{1}$, Intan Rahmayanti ${ }^{1}$, Supriatno Salam', Agus Safari ${ }^{1}$, Desi Harneti ${ }^{1}$, Rani Maharani ${ }^{1,2}$, \\ Ace Tatang Hidayat ${ }^{1,2}$, Mulyadi Tanjung ${ }^{3}$, Rurini Retnowati ${ }^{4}$, Yoshihito Shiono ${ }^{5}$ and Unang Supratman ${ }^{1,2^{*}}$
}

\begin{abstract}
A new havanensin-type limonoid, 16ß-hydroxydysobinin (1), along with four known limonoids (2-5), have been isolated from the seeds of Chisocheton macrophyllus. The chemical structure of the new compound was determined by referencing spectroscopic data, and by comparison to those related spectra previously reported. Each compound was evaluated for their cytotoxic effects against Michigan Cancer Foundation-7 (MCF-7) breast cancer cells and display no significant activity.
\end{abstract}

Keywords: 16ß-hydroxydysobinin, Chisocheton macrophyllus, MCF-7, Limonoid, Meliaceae

\section{Introduction}

Limonoids, known as degraded triterpenes, are derived from a precursor with a 4,4,8-trimethyl-17-furanylsteroid four-ring skeleton labelled as A, B, C and D rings [1]. Limonoids are a class of secondary metabolites found in the order Rutales and the Meliaceae and Rutaceae family [2]. Meliaceae is a family of timber trees that are a rich source for limonoids and are widely distributed in tropical and subtropical regions with 50 genera and more than 1400 species [3, 4]. Limonoids isolated from species of the family Meliaceae have been reported to have biologically activity as antifeedant, antimicrobial, antimalarial, and cytotoxins [5-8]. Genus Chisocheton is the second largest in the family Meliaceae, consisting of more than 50 species distributed across Nepal, India, Bhutan, Myanmar, South China, Thailand, Indonesia, Malaysia, and Papua New Guinea [7, 9].

Chisocheton macrophyllus is a species distributed in the Nicobar Islands, peninsular Thailand, peninsular Malaysia, Singapore, Sumatera, Anambas Islands, Java and Borneo Islands [10]. Its seeds have been

\footnotetext{
*Correspondence: unang.supratman@unpad.ac.id

${ }^{1}$ Department of Chemistry, Faculty of Mathematics and Natural Sciences,

Universitas Padjadjaran, Jatinangor 45363, Indonesia

Full list of author information is available at the end of the article
}

reported to yield bioactive limonoids such as dysobinol, $7 \alpha$-hydroxyneotricilenone, dysobinin and nimonol with cytotoxic activity against P-388 murine leukemia cells [11], whereas the leaves to yield Epstein-Barr virus activation of Triterpenoids [12]. After further investigations for cytototoxic limonoids from the seeds of C. macrophyllus, we found and structural elucidation of a new havenensin-type limonoids (1) and four known limonoids (2-5), along with their cytotoxic activity against MCF-7 breast cancer cells. Herein, the isolation, structural elucidation and cytotoxic activity against MCF-7 breast cancer cells are discussed.

\section{Materials and methods \\ Plant materials}

Seeds of C. macrophyllus were collected from Bogor Botanical Garden, Bogor, West Java Province, Indonesia. The plant was identified by Mr. Harto, the staff of Bogoriense Herbarium, Research Center for Biology, Indonesia Science Institute, Bogor, Indonesia and a voucher specimen (No. Bo-1295453) was deposited at the Herbarium.

\section{Instruments and reagents}

Optical rotations were measured on a Perkin Elmer 341 Polarimeter (Waltham, MA, USA). UV spectra 
was measured using a TECAN Infinite M200 pro with $\mathrm{MeOH}$. Furthermore, the IR spectra and mass spectra were recorded on a One PerkinElmer spectrum-100 FT-IR in $\mathrm{KBr}$ and Waters Xevo QTOF MS, respectively. NMR spectra were obtained with Bruker Topspin at $500 \mathrm{MHz}$ for ${ }^{1} \mathrm{H}$ and $125 \mathrm{MHz}$ for ${ }^{13} \mathrm{C}$ (compound 1) and for compounds 2-5 using JEOL JNM-ECZ500R/ $\mathrm{S} 1 \mathrm{at} 500 \mathrm{MHz}$ for ${ }^{1} \mathrm{H}$ and $125 \mathrm{MHz}$ for ${ }^{13} \mathrm{C}$, using tetra methylsilane (TMS) as the internal standard. Chromatographic separations were carried out on the silica gel 60 (70-230 and 230-400 mesh, Merck). Thin layer chromatography (TLC) analysis was carried out on $60 \mathrm{GF}_{254}$ (Merck, $0.25 \mathrm{~mm}$ ) using various solvent systems, and measured by irradiation under ultraviolet-visible light Vilber Lourmat $(\lambda 254 \mathrm{~nm}$ dan $365 \mathrm{~nm}$ ) followed by heating of silica gel plates, sprayed with $10 \% \mathrm{H}_{2} \mathrm{SO}_{4}$ in ethanol and Ehrlich's reagent ( $p$-Dimethylaminobenzaldehyde in ethanol).

\section{Extraction and isolation of C. macrophyllus}

The dried and powdered seeds of C. macrophyllus $(2.5 \mathrm{~kg})$ were extracted with methanol at room temperature for 3 days $(3 \times 5 \mathrm{~L})$. After removal of the solvent under a vacuum, a total of $360 \mathrm{~g}$ of methanol extract was obtained and partitioned with $n$-hexane $(3 \times 3 \mathrm{~L})$, ethyl acetate $(3 \times 2 \mathrm{~L})$ and $n$-butanol $(3 \times 2$ L). Evaporation resulted in crude extracts of $n$-hexane (146.6 g), ethyl acetate (60.8 g) and $n$-butanol (14.6 g) respectively. The $n$-hexane soluble fraction $(140 \mathrm{~g})$ was subjected to vacuum-liquid chromatography (VLC) column packed with silica gel 60 using a gradient of $n$-hexane, ethyl acetate and methanol (10\% stepwise) to afford thirteen fractions (A-M). Fraction D (5.4 g) was subjected to silica gel column chromatography using a gradient of $n$-hexane and ethyl acetate (5\% stepwise) as eluting solvent to afford five subfractions (D1-D5). Subfraction D2 (165.7 mg) was chromatographed on a column of silica gel eluted with $n$-hexane: dichloromethane: ethyl acetate (2:7.5:0.5) to give $\mathbf{1}(15.3 \mathrm{mg})$. Fraction F (4.4 g) was subjected to a silica gel column chromatography using a gradient of $n$-hexane and ethyl acetate (5\% stepwise) as eluting solvent to afford twelve subfractions (F1-F12). Subfraction F5 (1.2 g) was chromatographed on a column of silica gel eluted with $n$-hexane: dichloromethane: ethyl acetate (2:7.5:0.5) to give $3(19.7 \mathrm{mg})$ and four subfractions (F5A-F5D). Furthermore, subfraction F5D (308.3 mg) was chromatographed on a column of silica gel eluted with $n$-hexane: dichloromethane: ethyl acetate $(1: 8.5: 0.5)$ to give 2 (12.8 mg). Fraction $\mathrm{H}(1.8 \mathrm{~g})$ was subjected to a silica gel column chromatography using a gradient of $n$-hexane and ethyl acetate (5\% stepwise) as eluting solvent to give $5(12.0 \mathrm{mg})$. Fraction $\mathrm{J}(1.5 \mathrm{~g})$ was subjected to a silica gel column chromatography using a gradient of $n$-hexane and ethyl acetate ( $5 \%$ stepwise) to afford nineteen subfractions (J1-J19). Subfraction J9 (50.3 mg) was chromatographed on a column of silica gel eluted with $n$-hexane: dichloromethane: ethyl acetate (4:5.5:0.5) to give $4(3.0 \mathrm{mg})$.

16 $\beta$-hydroxydysobinin (1): Colorless needle crystals; mp: $205-207{ }^{\circ} \mathrm{C} ;[\alpha]^{27}{ }_{\mathrm{D}}+122.5^{\circ}(c \quad 0.2, \mathrm{MeOH})$; UV $(\mathrm{MeOH}) \lambda_{\max } 284 \mathrm{~nm}$; IR (KBr) $v_{\max } 3509,2929,1744$, 1670, 1502, 1366, 1386, $1248 \mathrm{~cm}^{-1}$; HR-TOFMS $\mathrm{m} / \mathrm{z}$ 511.2634 $[\mathrm{M}+\mathrm{H}]^{+}$, (calcd. for $\mathrm{C}_{30} \mathrm{H}_{39} \mathrm{O}_{7} \mathrm{~m} / z$ 511.2696); ${ }^{1} \mathrm{H}-\mathrm{NMR}\left(\mathrm{CDCl}_{3}, 500 \mathrm{MHz}\right)$ and ${ }^{13} \mathrm{C}-\mathrm{NMR}\left(\mathrm{CDCl}_{3}\right.$, $125 \mathrm{MHz}$ ) see Table 1.

Table 1 NMR spectral data for $1\left(500 \mathrm{MHz}\right.$ for ${ }^{1} \mathrm{H}$ and $125 \mathrm{MHz}$ for ${ }^{13} \mathrm{C}$ in $\mathrm{CDCl}_{3}$ )

\begin{tabular}{|c|c|c|}
\hline Position & $\delta_{H}\left(\sum H\right.$, mult., $\left.J=H z\right)$ & $\delta_{C}$ (mult.) \\
\hline 1 & $8.32(1 \mathrm{H}, \mathrm{d}, 10.5)$ & $158.1(d)$ \\
\hline 2 & $5.88(1 \mathrm{H}, \mathrm{d}, 10.5)$ & $124.5(d)$ \\
\hline 3 & - & $204.4(\mathrm{~s})$ \\
\hline 4 & - & $45.0(\mathrm{~s})$ \\
\hline 5 & $2.60(1 \mathrm{H}, \mathrm{d}, 12.5)$ & $47.5(d)$ \\
\hline 6 & $5.46(1 \mathrm{H}, \mathrm{m})$ & 69.7 (d) \\
\hline 7 & $5.41(1 \mathrm{H}, \mathrm{d}, 2.6)$ & 74.0 (d) \\
\hline 8 & - & $41.6(\mathrm{~s})$ \\
\hline 9 & $2.12(1 \mathrm{H}, \mathrm{dd}, 6.5,14.5)$ & $45.4(d)$ \\
\hline 10 & - & $42.7(s)$ \\
\hline \multirow[t]{2}{*}{11} & $1.86(1 \mathrm{H}, \mathrm{d}, 14.5)$ & $34.3(\mathrm{t})$ \\
\hline & $2.51(1 \mathrm{H}, \mathrm{m})$ & \\
\hline \multirow[t]{2}{*}{12} & $2.37(1 \mathrm{H}, \mathrm{m})$ & $46.4(t)$ \\
\hline & $1.67(1 \mathrm{H}, \mathrm{m})$ & \\
\hline 13 & - & $46.8(\mathrm{~s})$ \\
\hline 14 & - & $160.6(\mathrm{~s})$ \\
\hline 15 & $5.48(1 \mathrm{H}, \mathrm{d}, 7.7)$ & $119.3(d)$ \\
\hline 16 & $4.49(1 \mathrm{H}, \mathrm{t}, 7.7)$ & $67.2(d)$ \\
\hline 17 & $2.82(1 \mathrm{H}, \mathrm{dd}, 7.7,11.0)$ & $51.2(d)$ \\
\hline 18 & $1.33(3 \mathrm{H}, \mathrm{s})$ & $28.7(q)$ \\
\hline 19 & $1.28(3 \mathrm{H}, \mathrm{s})$ & $31.6(q)$ \\
\hline 20 & - & $124.0(\mathrm{~s})$ \\
\hline 21 & $7.28(1 \mathrm{H}, \mathrm{s})$ & 139.7 (d) \\
\hline 22 & $6.30(1 \mathrm{H}, \mathrm{d}, 1.4)$ & $110.9(d)$ \\
\hline 23 & $7.40(1 \mathrm{H}, \mathrm{d}, 1.4)$ & $142.7(d)$ \\
\hline 28 & $0.95(3 \mathrm{H}, \mathrm{s})$ & $20.5(q)$ \\
\hline 29 & $1.20(3 \mathrm{H}, \mathrm{s})$ & $20.6(q)$ \\
\hline 30 & $1.33(3 \mathrm{H}, \mathrm{s})$ & $20.9(q)$ \\
\hline $1^{\prime}$ & $2.04(3 \mathrm{H}, \mathrm{s})$ & $21.3(q)$ \\
\hline $2^{\prime}$ & - & $170.1(\mathrm{~s})$ \\
\hline $1^{\prime \prime}$ & $2.07(3 \mathrm{H}, \mathrm{s})$ & $22.0(q)$ \\
\hline $2^{\prime \prime}$ & - & $170.3(\mathrm{~s})$ \\
\hline
\end{tabular}




\section{Cytotoxic activity test}

The cytotoxicity of compounds $\mathbf{1 - 5}$ was determined with a cell viability test using PrestoBlue ${ }^{\circledR}$ assay. The cells were maintained in a Roswell Park Memorial Institute (RPMI) medium with 10\% (v/v) Fetal Bovine Serum (FBS) and $1 \mu \mathrm{L} / 1 \mathrm{~mL}$ antibiotics (1\% Penicillin-Streptomycin). Cultures were incubated at $37{ }^{\circ} \mathrm{C}$ in a humidified atmosphere of $5 \% \mathrm{CO}_{2}$. MCF-7 cells plated in 96 multiwell culture plates at a density of 1.7 $\times 10^{4}$ cells/well. After twenty-four hours, the medium was discarded and fresh medium containing sample with different concentrations $7.81,15.63,31.25,62.50$, $125.00,250.00,500.00,1000.00 \mu \mathrm{g} / \mathrm{mL}$ and control was added. After incubation with the sample for $24 \mathrm{~h}$, PrestoBlue $^{\circledR}$ reagent (resazurin dye) was added. The PrestoBlue ${ }^{\circledR}$ assay results were read using a multimode reader at $570 \mathrm{~nm}$. The $\mathrm{IC}_{50}$ values were determined by linier regression method using Microsoft Excel software. The $\mathrm{IC}_{50}$ value corresponds to the concentration of compounds that decreases by $50 \%$ the number of viable cells and the absorbance in control corresponds to $100 \%$ viability.

\section{Results and discussion}

The $n$-hexane fraction from the seeds of C. macrophyllus was subjected to vacuum-liquid chromatography (VLC) column packed with silica gel 60 by gradient elution. The VLC fractions were repeatedly subjected to normal phase column chromatography on silica gel to yield compounds 1-5 (Fig. 1).

Compound $\mathbf{1}$ was isolated as colorless needle crystals. The molecular formula was determined to be $\mathrm{C}_{30} \mathrm{H}_{39} \mathrm{O}_{7}$ based on the high resolution time-of-flight mass spectrometry (HR-TOFMS) spectra (Additional file 1; Fig. S8) at $m / z 511.2634[\mathrm{M}+\mathrm{H}]^{+}$(calcd. for $\mathrm{C}_{30} \mathrm{H}_{39} \mathrm{O}_{7} \mathrm{~m} / z$ 511.2696) and nuclear magnetic resonance (NMR) data (Table 1), indicating the presence of twelve degrees of unsaturation. The ultraviolet (UV) spectrum showed maximum absorption at $284 \mathrm{~nm}$, indicating the presence of an $\alpha, \beta$-unsaturated ketone [13, 14]. Infrared (IR) absorptions spectra suggested the presence of hydroxyl (3509 $\left.\mathrm{cm}^{-1}\right)$, aliphatic $\left(2929 \mathrm{~cm}^{-1}\right)$, carbonyl ester $\left(1744 \mathrm{~cm}^{-1}\right), \alpha, \beta$-unsaturated carbonyl $\left(1670 \mathrm{~cm}^{-1}\right)$, olefinic $\left(1502 \mathrm{~cm}^{-1}\right)$, gem-dimethyl $\left(1366\right.$ and $1386 \mathrm{~cm}^{-1}$ ) and ether groups $\left(1248 \mathrm{~cm}^{-1}\right)$.

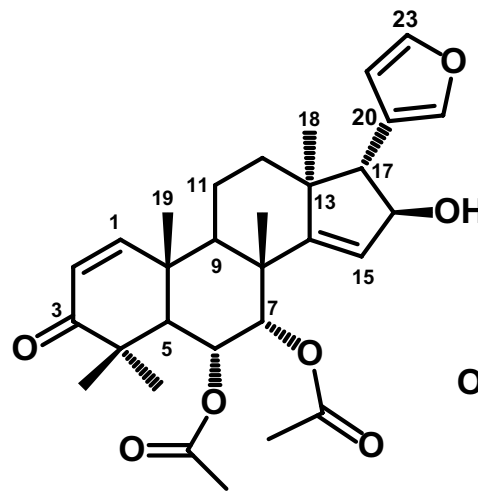

1

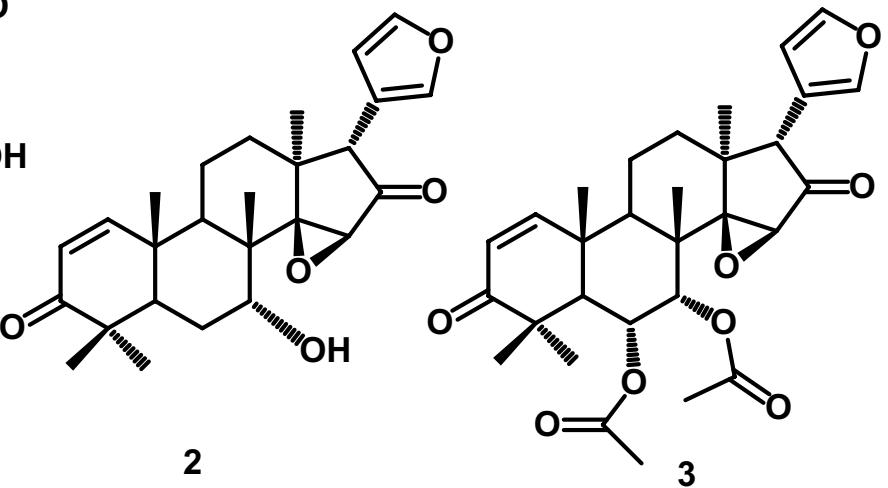

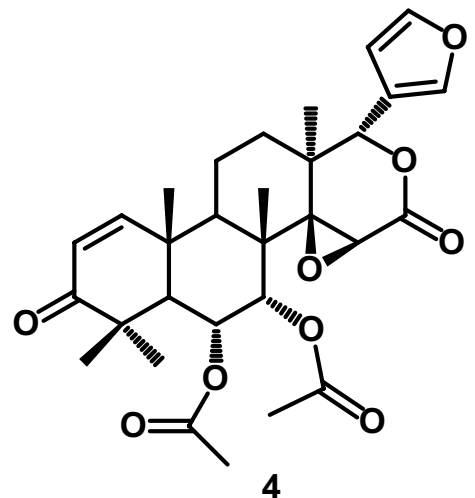<smiles>CC(=O)O[C@@H]1[C@H](OC(C)=O)[C@H]2C(C)(C)C(=O)C=C[C@]2(C)C2CC[C@@]3(C)C(=CC[C@@H]3c3ccoc3)[C@]21C</smiles>

Fig. 1 Structures of compounds $\mathbf{1 - 5}$ 
The ${ }^{1} \mathrm{H}-\mathrm{NMR}$ spectrum (Additional file 1; Fig. S1) showed five tertiary methyls at $\delta_{\mathrm{H}} 0.95(3 \mathrm{H}, \mathrm{s}$, Me-28), 1.20 (3H, s, Me-29), 1.28 (3H, s, Me-19), and 1.33 $(6 \mathrm{H}, \mathrm{s}, \mathrm{Me}-18$ and $\mathrm{Me}-30)$ as well as two acetoxyl groups at $\delta_{\mathrm{H}} 2.04\left(3 \mathrm{H}, \mathrm{s}, \mathrm{Me}-1^{\prime}\right)$ and $2.07\left(3 \mathrm{H}, \mathrm{s}, \mathrm{Me}-1^{\prime \prime}\right)$. In addition, three oxygenated protons $\delta_{\mathrm{H}} 5.46(1 \mathrm{H}, \mathrm{m}, \mathrm{H}-6), 5.41$ $(1 \mathrm{H}, \mathrm{d}, J=2.6 \mathrm{~Hz}, \mathrm{H}-7)$ and $4.49(1 \mathrm{H}, \mathrm{t}, J=7.7 \mathrm{~Hz}, \mathrm{H}-16)$, a $\beta$-furan moiety $\delta_{\mathrm{H}} 6.30(1 \mathrm{H}, \mathrm{d}, J=1.45 \mathrm{~Hz}, \mathrm{H}-22), 7.28$ $(1 \mathrm{H}, \mathrm{s}, \mathrm{H}-21)$, and $7.40(1 \mathrm{H}, \mathrm{d}, J=1.45 \mathrm{~Hz}, \mathrm{H}-23)$ and three olefinic protons at $\delta_{\mathrm{H}} 5.48(1 \mathrm{H}, \mathrm{d}, J=7.7 \mathrm{~Hz}, \mathrm{H}-15)$, $5.88(1 \mathrm{H}, \mathrm{d}, J=10.5 \mathrm{~Hz}, \mathrm{H}-2)$ and $8.32(1 \mathrm{H}, \mathrm{d}, J=10.5 \mathrm{~Hz}$, $\mathrm{H}-1$ ) were also observed in the ${ }^{1} \mathrm{H}-\mathrm{NMR}$ spectrum. The ${ }^{13} \mathrm{C}$ NMR (Additional file 1; Fig. S2) along with distortions enhancement by polarization transfer (DEPT) (Additional file 1; Fig. S3) and heteronuclear single quantum coherence (HSQC) spectra (Additional file 1; Fig. S4) showed thirty carbons consisting of an $\alpha, \beta$-unsaturated carbonyl at $\delta_{\mathrm{C}} 204.4(\mathrm{C}-3)$, two acetoxyl groups at $\delta_{\mathrm{C}} 21.3$ $\left(\mathrm{C}-1^{\prime}\right), 170.1\left(\mathrm{C}-2^{\prime}\right), 22.0\left(\mathrm{C}-1^{\prime \prime}\right)$ and $170.3\left(\mathrm{C}-2^{\prime \prime}\right)$ and five methyls at $\delta_{\mathrm{C}} 20.5$ (Me-28), 20.6 (Me-29), 20.9 (Me-30), 28.7 (Me-18) and $31.6(\mathrm{Me}-19)$. The spectra also showed two methylene carbons at $\delta_{\mathrm{C}} 34.3(\mathrm{C}-11)$ and $46.4(\mathrm{C}-12)$, three $\mathrm{sp}^{3}$ methine carbons at $\delta_{\mathrm{C}} 45.4$ (C-9), 47.5 (C-5) and $51.2(\mathrm{C}-17)$, four $\mathrm{sp}^{2}$ methine carbons at $\delta_{\mathrm{C}} 110.9$ (C-22), 119.3 (C-15), 124.5 (C-2) and 158.1 (C-1), three oxygenated $\mathrm{sp}^{3}$ methine carbons at $\delta_{\mathrm{C}} 67.2$ (C-16), 69.7 $(\mathrm{C}-6)$ and $74.0(\mathrm{C}-7)$, two oxygenated $\mathrm{sp}^{2}$ methine carbons at $\delta_{\mathrm{C}} 139.7(\mathrm{C}-21)$ and $142.7(\mathrm{C}-23)$, four sp ${ }^{3}$ quaternary carbons at $\delta_{C} 41.6(\mathrm{C}-8), 42.7(\mathrm{C}-10), 45.0(\mathrm{C}-4)$, and $46.8(\mathrm{C}-13)$ and two $\mathrm{sp}^{2}$ quaternary carbons at $\delta_{\mathrm{C}} 124.0$ (C-20) and 160.6 (C-14). These functionalities accounted for seven out of the twelve degrees of unsaturation, while the remaining five degrees of unsaturation corresponded to the pentacyclic limonoid structure $[6,11,15,16]$. The NMR spectra data of 1 resembled those of previously reported dysobinin $[16,17]$, except for the appearance of oxygenated signals $\left[\delta_{\mathrm{H}} 4.49(1 \mathrm{H}, \mathrm{t}, J=7.7 \mathrm{~Hz}), \delta_{\mathrm{C}} 67.2\right]$, thus suggesting that 1 was a hydroxyl analog of dysobinin. Position of the hydroxyl group at $\mathrm{C}-16$ was determined through the ${ }^{1} \mathrm{H}-{ }^{1} \mathrm{H}$ correlated spectroscopy $\left({ }^{1} \mathrm{H}-{ }^{1} \mathrm{H}\right.$ COSY) and proton multiple bond connectivity (HMBC) experiments (Fig. 2, Additional file 1; Fig. S5 and Fig. S6). Correlations from methyl protons at $\delta_{\mathrm{H}} 1.33\left(\mathrm{CH}_{3}-18\right)$ to $\delta_{\mathrm{C}} 51.2(\mathrm{C}-17)$, oxygenated $\mathrm{sp}^{3}$ methine at $\delta_{\mathrm{H}} 4.49(\mathrm{H}-16)$ to $\delta_{\mathrm{C}} 124.0(\mathrm{C}-20)$ and methyne proton $\delta_{\mathrm{H}} 2.82(\mathrm{H}-17)$ to $\delta_{\mathrm{C}} 139.7(\mathrm{C}-21)$ and $\delta_{\mathrm{C}} 110.9(\mathrm{C}-22)$ were used to assign the hydroxyl group and a furan ring attached at C-16 and C-17, respectively.

Based on the ${ }^{1} \mathrm{H}-{ }^{1} \mathrm{H}$ COSY spectrum of 1 , correlation in $\mathrm{H}_{1}-\mathrm{H}_{2}, \mathrm{H}_{5}-\mathrm{H}_{6}-\mathrm{H}_{7}, \mathrm{H}_{9}-\mathrm{H}_{11}-\mathrm{H}_{12}, \mathrm{H}_{16}-\mathrm{H}_{17}$ and $\mathrm{H}_{22}-\mathrm{H}_{23}$ supported the presence of a havanensin-type limonoid structure in $\mathbf{1}[15,17,18]$. The HMBC spectrum showed ${ }^{3} \mathrm{~J}$ correlations between $\mathrm{sp}^{2}$ methine proton signal $\delta_{\mathrm{H}}$
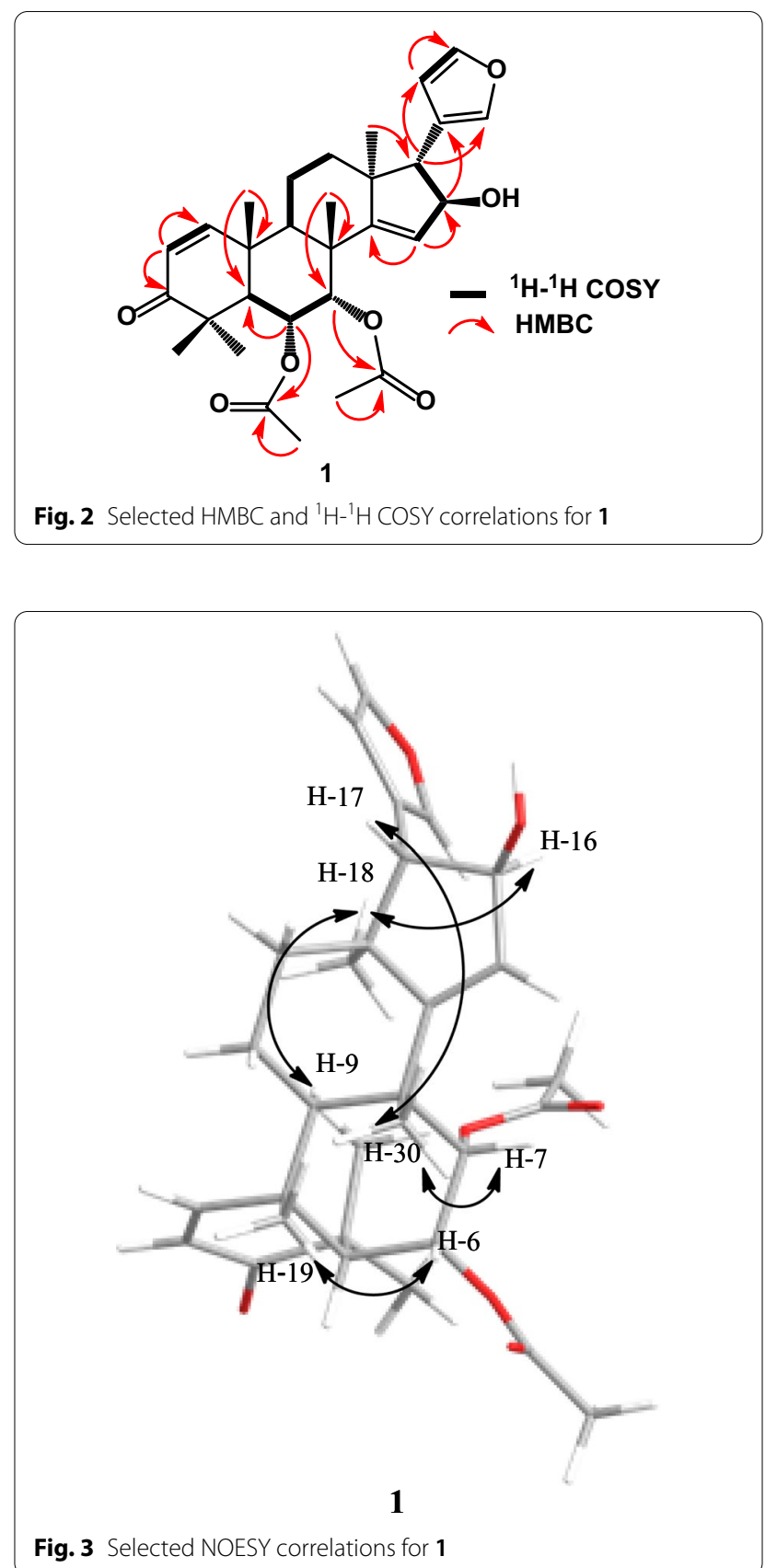

$8.32(\mathrm{H}-1)$ to $\delta_{\mathrm{C}} 47.5(\mathrm{C}-5)$ and carbonyl at $\delta_{\mathrm{C}} 204.4(\mathrm{C}-3)$ and $\delta_{\mathrm{H}} 5.88(\mathrm{H}-2)$ to $\delta_{\mathrm{C}} 42.7(\mathrm{C}-10)$, indicating the presence of $\alpha, \beta$-unsaturation ketone located at $\mathrm{C}-1, \mathrm{C}-2$ and $\mathrm{C}-3$, respectively. Correlations from oxygenated $\mathrm{sp}^{3}$ methine protons at $\delta_{\mathrm{H}} 5.46(\mathrm{H}-6)$ to $\delta_{\mathrm{C}} 45.0(\mathrm{C}-4)$ and $\delta_{\mathrm{C}}$ $170.1\left(\mathrm{C}-2^{\prime}\right)$ and $\delta_{\mathrm{H}} 5.41(\mathrm{H}-7)$ to $\delta_{\mathrm{C}} 45.4(\mathrm{C}-9)$ as well as $\delta_{\mathrm{H}} 2.04\left(\mathrm{H}-1^{\prime}\right)$ to $\delta_{\mathrm{C}} 170.1\left(\mathrm{C}-2^{\prime}\right)$ and $\delta_{\mathrm{H}} 2.07\left(\mathrm{H}-1^{\prime \prime}\right)$ to $\delta_{\mathrm{C}}$ $170.3\left(\mathrm{C}-2^{\prime \prime}\right)$, indicate that an acetyl group was attached at C-6 and C-7, respectively. 
The relative stereochemistry of hydroxyl group at $\mathrm{C}-16$ of 1 was determined by a nuclear overhauser and exchange spectroscopy (NOESY) experiment (Fig. 3 and Additional file 1; Fig. S7). Comparison of oxygenated $\mathrm{sp}^{3}$ methine protons at $\delta_{\mathrm{H}} 4.49(\mathrm{H}-16)$ and $\mathrm{CH}_{3}-18\left(\delta_{\mathrm{H}} 1.33\right)$ with $\alpha$-oriented, indicated that $\mathrm{H}-16$ was $\alpha$-oriented and hydroxyl group at $\mathrm{C}-16$ is $\beta$-oriented. Correlations between $\delta_{\mathrm{H}} 5.41(\mathrm{H}-7)$ and $\mathrm{CH}_{3}-30\left(\delta_{\mathrm{H}} 1.33\right)$ with $\beta$-oriented, indicated that $\mathrm{H}-7$ was $\beta$-oriented and acetyl group at C-7 is $\alpha$-oriented. Correlations between $\delta_{\mathrm{H}} 5.46(\mathrm{H}-6)$ and $\mathrm{CH}_{3}-19\left(\delta_{\mathrm{H}} 1.28\right)$ with $\beta$-oriented, indicated that $\mathrm{H}-6$ was $\beta$-oriented and acetyl group at C- 6 is $\alpha$-oriented. Furthermore, the optical rotation of $\mathbf{1},[\alpha]^{27}{ }_{\mathrm{D}}+122.5^{\circ}(c 0.2$, $\mathrm{MeOH})$ is the same sign to those of previously reported dysobinin (6) $\left([\alpha]^{20}{ }_{D}+150^{\circ}\right)[17,18]$. Therefore, the structure of 1 was elucidated as the new havanensin-type of limonoid derivative and named 16 $\beta$-hydroxydysobinin.

Four known compounds, 7-deacetylepoxyazadiradione (2), were previously synthesized as a derivative of epoxyazadiradione $[19,20]$, but isolated from a natural source for the first time. In addition, $6 \alpha$-acetoxyepoxyazadiradione (3) and $6 \alpha$-acetoxygedunin (4) [21] as well as dysobinin (5) $[11,17,18]$ were identified by comparison of their spectroscopic data with previously reported values.

\section{Cytotoxic activity}

All isolated compounds were evaluated for the cytotoxic activity against MCF-7 breast cancer cell line and cisplatin is used as a positive control according to the method previously described $[16,22]$ and the results are shown in Table 2. Compound $\mathbf{1}$ showed the strongest activity against MCF-7 breast cancer cell with $\mathrm{IC}_{50}$ (inhibitory concentration, $50 \%$ ) values of $45.91 \mu \mathrm{M}$, suggesting that the presence of hydroxyl at C-16 can increase the cytotoxic activity. In addition, the presence of epoxy ring and ketone group, like in compound 2-4, showed weak activity, indicated the presence of epoxy ring and ketone group can decrease activity.

Table 2 Cytotoxicity activity of compounds $\mathbf{1 - 5}$ against MCF-7 breast cancer cell line

\begin{tabular}{lc}
\hline Compounds & $\mathrm{IC}_{50}(\mu \mathrm{M})$ \\
\hline 16ß-hydroxydysobinin (1) & 45.91 \\
7-deacetylepoxyazadiradione (2) & 94.62 \\
$6 \alpha$-acetoxyepoxyazadiradione (3) & 105.16 \\
$6 \alpha$-acetoxygedunin (4) & 121.82 \\
Dysobinin (5) & 68.15 \\
Cisplatin* & 38.06 \\
\hline
\end{tabular}

\section{Supplementary Information}

The online version contains supplementary material available at https://doi. org/10.1186/s13765-021-00606-5.

Additional file 1: Figure S1. ${ }^{1} \mathrm{H}-\mathrm{NMR}$ Spectrum of $1\left(500 \mathrm{MHz}\right.$ in $\left.\mathrm{CDCl}_{3}\right)$. Figure S2. ${ }^{13} \mathrm{C}-\mathrm{NMR}$ Spectrum of $\mathbf{1}\left(125 \mathrm{MHz}\right.$ in $\left.\mathrm{CDCl}_{3}\right)$. Figure S3. DEPT$135^{\circ}$ Spectrum of $\mathbf{1}\left(135 \mathrm{MHz}\right.$ in $\left.\mathrm{CDCl}_{3}\right)$. Figure S4. HSQC Spectrum of $\mathbf{1}$. Figure S5. ${ }^{1} \mathrm{H}-{ }^{1} \mathrm{H}$ COSY Spectrum of $\mathbf{1}$. Figure S6. HMBC Spectrum of $\mathbf{1}$. Figure S7. ${ }^{1} \mathrm{H}-{ }^{1} \mathrm{H}-\mathrm{NOESY}$ Spectrum of 1. Figure S8. HRTOFMS spectrum of 1. Figure S9. ${ }^{1} \mathrm{H}-\mathrm{NMR}$ Spectrum of $\mathbf{2}\left(500 \mathrm{MHz}\right.$ in $\left.\mathrm{CDCl}_{3}\right)$. Figure $\mathbf{S 1 0}$. ${ }^{13} \mathrm{C}-\mathrm{NMR}$ and DEPT- $135^{\circ}$ Spectrum of $\mathbf{2}$. Figure S11. HMQC Spectrum of $\mathbf{2}$. Figure S12. ${ }^{1} \mathrm{H}-{ }^{1} \mathrm{H}$ COSY Spectrum of $\mathbf{2}$. Figure S13. HMBC Spectrum of 2. Figure S14. ${ }^{1} \mathrm{H}-{ }^{1} \mathrm{H}-\mathrm{NOESY}$ Spectra of $\mathbf{2}$. Figure S15. HRTOFMS spectrum of 2 .

\section{Acknowledgements}

This investigation was financially supported by Universitas Padjadjaran, Indonesia (PPKI Grant, No: 1427/UN6.3.1/LT/2020 by US) by Airlangga University, Indonesia (PPKI Grant, No: 305/UN3.14/PT/2020 by MT) and Brawijaya University, Indonesia (PPKI Grant, No: 455.5/UN10.C10/PN/2020 by RR).

\section{Authors' contributions}

NS, IR and SS: Isolation of limonoid from the $n$-hexane extract; AS, DH, RM, ATH, MT: Structural elucidation of isolated compounds; RR, DH: cytotoxic assay; NS, IR, US, YS: preparing and completing manuscript. All authors read and approved the final manuscript.

\section{Declarations}

\section{Competing interests}

There is so conflict of interests.

\section{Author details}

${ }^{1}$ Department of Chemistry, Faculty of Mathematics and Natural Sciences, Universitas Padjadjaran, Jatinangor 45363, Indonesia. ${ }^{2}$ Central Laboratory, Universitas Padjadjaran, Jatinangor 45363, Indonesia. ${ }^{3}$ Department of Chemistry, Faculty of Science and Technology, Universitas Airlangga, Surabaya 60286, Indonesia. ${ }^{4}$ Department of Chemistry, Faculty of Mathematics and Natural Sciences, Universitas Brawijaya, Malang 65145, Indonesia. ${ }^{5}$ Department of Food, Life, and Environmental Science, Faculty of Agriculture, Yamagata University, Tsuruoka, Yamagata 997-8555, Japan.

Received: 25 January 2021 Accepted: 22 March 2021

Published online: 07 April 2021

\section{References}

1. Fang X, DiYT, Hao XJ (2011) The advances in the limonoid chemistry of the Meliaceae Family. Curr Org Chem 15:1363-1391

2. Li H, Peng Y, Zheng J (2016) (2016) Metabolic activation and toxicities of furanoterpenoids. AdvMo|Toxicol 10:55-97

3. Paritala V, Chiruvella KK, Thammineni C, Ghanta RG, Mohammed A (2015) Phytochemicals and antimicrobial potentials of mahogany family. Rev Bras Farmacogn 25:61-83

4. Tan QD, Luo XD (2011) MeliaceousLimonoids: chemistry and biological activities. Chem Rev 111:7437-7522

5. Yang MH, Wang JS, Luo JG, Wang XB, Kong LY (2009) Tetranortriterpenoids from Chisocheton paniculatus. J Nat Prod 72:2014-2018

6. Wong CP, Shimada M, Nagakura Y, Nugroho AE, Hirasawa Y, Taneda T, Awang K, Hadi AHA, Mohamad K, Shiro M, Morita H (2011) Ceramicines E-I, new limonoids from Chisocheton ceramicus. Chem Pharm Bull 59:407-411

7. Shilpi JA, Sahab S, Chong SL, Nahard L, Sarkerd SD, Awang K (2016) Advances in chemistry and bioactivity of the genus Chisocheton BLUME. Chem Biodiv 13:483-503

* Positive control 
8. Chong SL, Hematpoor A, Hazni H, Azirun MS, Litaudon M, Supratman U, Murata M, Awang K (2019) Mosquito larvacidal limonoids from the fruits of Chisocheton erythrocarpus Hiern. Phytochem Lett 30:69-73

9. Katja DG, Farabi K, Nurlelasari HD, Mayanti T, Supratman U, Awang K, Hayashi H (2017) Cytototoxic constituents from the bark of Chisocheton cumingianus (Meliaceae). J Asian Nat Prod Res 6:1-5

10. Vossen VD and Umali BE (2002) Plant Resources of South East Asia, No. 14 Vegetable oil and fats, Prosea Foundation, Bogor, Indonesia.

11. Nurlelasari KDG, Harneti D, Wardayo MM, Supratman U, Awang K (2017) Limonoids from the seeds of Chisocheton macrophyllus. Chem Nat Compd 53:83-87

12. Inada A, Somekawa M, Murata H, Nakanishi T, Tokuda H, Nishino H, Iwashima A, Darnaedi D, Murata J (1993) Phytochemical studies on meliaceous plants. VIII structures and inhibitory effects on Epstein-Barr Virus activation of triterpenoids from leaves of Chisocheton macrophyllus KING. Chem Pharm Bull 41(3), 617-619.

13. Shiono $Y$, Miyazani N, Murayama T, Koseki T, Harizon KDG, Supratman U, Nakata J, Kakihara Y, Saeki M, Yoshida J, Uesugi S, Kimura K (2016) GSK-3ß inhibitory activities of novel dichloresorcinol derivatives from Cosmospora vilior isolated from a mangrove plant. Phytochem Lett 18:122-127

14. Aisyah LS, Yun YF, Herlina T, Julaeha E, Zainuddin A, Nurfarida I, Hidayat AT, Supratman U, Shiono Y (2017) Flavonoid compounds from the leaves of Kalanchoe prolifera and their cytotoxic activity against P-388 murine leukimia cells. Nat Prod Sci 23(2):139-145

15. Najmuldeen IA, Hadi AHA, Mohamad K, Awang K, Ketuly KA, Mukhtar MR, Taha H, Nordin M, Litaudon M, Gueritte F, Nugroho AE, Morita H (2012) Chisomicines $\mathrm{D}$ and $\mathrm{E}$, two new limonoids from Chisocheton ceramicus. Heterocycles 84:1265-1270
16. Supriatno S, Nurlelasari HT, Harneti D, Maharani R, Hidayat AT, Mayanti T, Supratman U, Azmi MN, Shiono Y (2018) A new limonoid from stem bark of Chisocheton pentandrus (Meliaceae). Nat Prod Res 25:1-7

17. Singh S, Garg HS, Khanna NM (1976) Dysobinin, a new tetranortriterpene from Dysoxylum binectariferum. Phytochemistry 15:2001-2002

18. Maneerat WS, Laphookhieo S, Koysomboon K, Chantrapromma K (2008) Antimalarial, antimycobacterial and cytotoxiclimonoids from Chisocheton siamensis. Phytomedicine 15:1130-1134

19. Haldar S, Kolet SP, Thulasiram HV (2013) Biocatalysis: fungi mediated nove and selective $12 \beta$-or $17 \beta$-hydroxylation on the basic limonoid skeleton. Green Chem 15:1311-1317

20. Yadav PA, Kumar CP, Siva B, Babu KS, Allanki AD, Sijwali PS, Jain N, Rao AV (2017) Synthesis and evaluation of anti-plasmodial and cytotoxic activities of epoxyazadiradione derivatives. Euro J of Med Chem 134:242-257

21. Pereira TB, Silva L, Amorim R, Melo M, Souza R, Eberlin M, Lima ES, Vasconcellos MC, Pohlit AM (2014) In vitro and in vivo anti-malarial activity of limonoids isolated from the residual seed biomass from Carapa guianensis (andiroba) oil production. Malar J 13:317

22. Examinati RRIN, Wulandari AP, Harneti D, Poniah A (2018) Cytotoxicity of aromatic compound from an endophytic fungus, Cladosporium sp EN-S01 Int J of Curr Pharm Res, 10, 10-12.

\section{Publisher's Note}

Springer Nature remains neutral with regard to jurisdictional claims in published maps and institutional affiliations.

\section{Submit your manuscript to a SpringerOpen ${ }^{\circ}$ journal and benefit from:}

- Convenient online submission

- Rigorous peer review

- Open access: articles freely available online

- High visibility within the field

Retaining the copyright to your article

Submit your next manuscript at springeropen.com 